\title{
Work-Family Conflict among Employees: What is the Role of Religiosity on Job Satisfaction and Performance
}

\author{
Fatrilia Rasyi Radita ${ }^{1}$, Whan Augustin Ainul Amri ${ }^{2}$, Nana Supiana ${ }^{3}$ Ipang Sasono ${ }^{4}$, Tias Pramono ${ }^{5}$, \\ Dewiana Novitasari ${ }^{6 *}$, Gusli Chidir $^{7}$, Sri Wahyuni Asnaini ${ }^{8}$ \\ 1,3,4,7 STMIK Insan Pembangunan, Indonesia \\ ${ }^{2,5,6,8}$ Sekolah Tinggi Ilmu Ekonomi Insan Pembangunan, Indonesia
}

\begin{abstract}
The purpose of this research is to analyse the effect of religiosity and work-family conflict towards employee performance through job satisfaction as an intervening variable to the workers of the manufacturing industry by taking 120 workers as samples. This research used a questionnaire as the method of data collection. Whereas, the analysis method used Structural Equation Modelling (SEM), SmartPLS v.3.0. The result of this research showed that religiosity has a significant positive effect on job satisfaction, the work-family conflict has a significant negative effect on job satisfaction, religiosity has a significant positive effect on employee performance, work-family conflict does not significantly affect employee performance, job satisfaction has a significant positive effect to employee performance, religiosity has a significant positive effect to employee performance through job satisfaction as an intervening variable, work-family conflict does not significantly affect the employee performance through job satisfaction as an intervening variable. The result of this research could be used as a basis to improve and maintain a company's performance through religious improvement and concern towards work-family conflict experienced by the workers.
\end{abstract}

Keywords: Job satisfaction, employee performance, religiosity, work-family conflict.

\section{INTRODUCTION}

The success of a particular organization has a close relationship with the quality of its member's performance, so the organization is required to always develop human resource and improve the performance of the members through the creation of the worker's job satisfaction (Hutagalung et al., 2020; Jumiran et al., 2020; Nuryanti et al., 2020; Sutardi et al., 2020; Yuwono et al., 2020; Yuwono, Novitasari, Hutagalung, et al., 2020). One of the problems faced when managing human resources is job satisfaction. Satisfied workers have little possibility of resigning, so customers will often meet familiar faces and receive experienced service (Goestjahjanti et al., 2020; Novitasari, Asbari, et al., 2020; Silitonga et al., 2020; Sudiyono et al., 2020). These characteristics will develop the satisfaction and loyalty of the customers. The worker who feels satisfied in their work tend to have a better attendance record and regulatory compliance, but less active in participating in the labor union activities. This worker will also usually have a better achievement compared with the workers who are not satisfied in their job (Aminiar et al., 2020; Basuki et al., 2020; Hutagalung, Sopa, et al., 2020; Kamar et al., 2019; Lestari et al., 2020; Novitasari, Sasono, et al., 2020; Zaman et al., 2020).

In a various research, performance is usually affected by work-family conflict (Asbari et al., 2020a; Novitasari, Sasono, et al., 2020). The work-family conflict occurred when one of the roles in a job demands or need more attention than a role in a family. However, not all of them can align roles in a job and family, which ends in a work-family conflict(Novitasari, Sasono, et al., 2020; Sutardi et al., 2020). Other than work-family conflict, religiosity could also influence the improvement of employee performance (Hutagalung, Asbari, et al., 2020; Maesaroh et al., 2020). Religiosity refers to understanding and appreciating someone's religion and religious experiences in their daily behavior. The values contained in religious teachings and rules tend to be bounded and should be obeyed by the believers, including the young believers as well (Aman et al., 2019). The higher the religiosity of a particular person, the better their performance will be. The linkage between work-family conflict and religiosity with job satisfaction and performance is considered to determine the organization's ability to overcome changes in the environment, even directly affecting the employee performance, which one of them is a manufacturing organization. Measurement of employee performance in a manufacturing industry is by using a measuring tool or indicator of Performance Assessment (PA), where PA should be able to be easily understood and implemented. The result of the researcher's observations related to employee performance indicates that the 
manufacturing service workers are relatively different from each other. This is indicated through the different quality of work results, the worker's knowledge, and the independence in working.

\section{LITERATURE REVIEW AND HYPOTHESIS DEVELOPMENT}

\section{A. Religiosity}

One of the important individual norms is religion and belief. Stereotypically, religiosity is defined as understanding the knowledge and belief of a certain religion, other than the influence that is related to the emotional bound or feelings towards religion. Next, religious behavior is expressed, such as membership and attendance in religious activities, reading scriptures, and also praying (Hichy et al., 2020; Rowatt \& Al-Kire, 2021; Xia et al., 2021). The trend towards belief shows the religiosity of someone to a set of principles that gives some social control to the concerned individuals (Jiménez et al., 2019). Two typical aspects of religiosity are put forward by Ramlee et al. (2016), which are extrinsic religiosity and intrinsic religiosity. Religious behavior is basically from the extrinsic aspect, when the use of religiosity is for the personal interest, especially to get popularity, target business achievements, or friendship. Whereas intrinsic religious dimension is based on the natural purposes, that is guiding someone to obey the religious teachings by praying or involved in a voluntary community service (Charan et al., 2020; Choy, 2020; Jiménez et al., 2019). Indicator/items of the instrument from the variable of religiosity in this study are adapted by Ramlee et al. (2016), which consist of five indicators/items cited in Table 1.

\section{B. Work-Family Conflict}

According to Greenhaus \& Beutell (1985), work-family conflict is one of the inter-role conflict forms, that is the pressure or the imbalance within roles in a family. High working hours and workload are a direct sign where the work-family conflict will occur due to the overuse of time and effort to work. This could lead to the lack of time and energy that can be used to do family activities. Greenhaus \& Beutell (1985) visualize the types of conflictrelated to the dilemmas of roles of women between household and job. Firstly, time-based conflict, which is the conflict that occurs when time is used to fulfill one role but unable to be used to fulfill the other roles, involving the division of time, energy, and changes between roles in work and household. In this case, arranging a schedule is considered to be difficult and limited to the time when demand and behavior needed to portray both roles do not correspond to each other. Secondly, strain-based conflict, which refers to the emergence of tension or emotional condition resulted from one of the roles that make someone difficult to satisfy the other role demand. As an example, a mother that works from nine-to-five would feel exhausted and it would be difficult for them to sit comfortably while accompanying their children doing homework. The tension of this role may involve stress, increase in blood pressure, anxiety, emotional condition, and also headache. Thirdly, behaviorbased conflict, which is the conflict that occurs when an expectation of a certain behavior is different from the expectation of another role. The discrepancy of an individual's behavior at the workplace and home is caused by the difference in rules of behavior from a career woman that is usually difficult to exchange the roles. Indicator/items of the instrument from a work-family conflict variable in this study are adapted by VU (2020) consisting of five indicators/items cited in Table 1.

\section{Job Satisfaction}

Job satisfaction is an emotional condition that is exciting or positive resulted from someone's judgment towards job or experience (Armstrong et al., 2015; Baluyos et al., 2019; Chordiya et al., 2017; Eliyana et al., 2019; Hedayat et al., 2018; Qureshi et al., 2019; Sabahi \& Sanai Dashti, 2016). In other words, job satisfaction is the positive or negative emotion as a result of a worker's evaluation regarding the level of satisfaction towards their job. Therefore, job satisfaction becomes one of the organizational variables that is frequently measured in research and has been studied a lot in organizational behavior, since job satisfaction could be an important indicator of how the worker's feelings towards their job and work behavior predictor like motivation, attendance, and performance (Bogler, 2001; Onyemah, Rouzie, et al., 2018). Indicator/items of the instrument from job satisfaction variable in this study is adapted by Armstrong et al. (2015) consisting of five indicators/items cited in Table 1. 


\section{Employee performance}

Performance is behavior on how a target is achieved (M. Armstrong \& Taylor, 2014). Performance is referred to as a goal-oriented process directed to ensure the organizational processes are at their place to maximize the productivity of the worker, team, and the organization itself. In another opinion, performance is referred to things that are done and not done by the workers (Luthans, 2005). To get to know the employee performance in an organization, certain aspects are needed. Performance is affected by the variable related to the job, involving role-stress and work/non-work conflict (Babin \& Boles, 1998). There are some criteria in measuring performance, which is: quality, quantity, punctuality, cost-effectivity, and interpersonal relationships (Bernardin \& Russel, 1993). Meanwhile, (Mathis \& Jackson, 2002) mentioned that employee performance has some elements, which consist of quantity, quality, accuracy, attendance, cooperation ability, and loyalty. Indicator/items of the instrument from the employee performance variable in this study is adapted by Dessler (2006) consisting of fifteen indicators/items cited in Table 1.

\section{E. The Influence of Religiosity on Worker's Job Satisfaction}

In the theory of religiosity, it explained that religiosity is the mastery of the knowledge, the strength of the belief, the perseverance of the worship implementation, and appreciation of the religion (Cohen et al., 2017; Hage \& Posner, 2015; Koenig et al., 2015). The result of research proved that religiosity positively influences the worker's job satisfaction (Amaliah et al., 2015; Bednarczuk, 2019; Darto et al., 2015; Onyemah, Rouziès, et al., 2018).

\section{H1: Religiosity is significantly influenced job satisfaction.}

\section{F. The Influence of Work-Family Conflict on Worker's Job Satisfaction}

Based on the theory of roles, a work-family conflict is a form of conflict within the roles, which is when the role pressures from work and family are contradicting so participation in one of the roles is more difficult due to the participation of other roles. The result of the research showed that work-family conflict negatively influences job satisfaction (Martinez-Sanchez et al., 2018). Likewise, research done by Rahman et al. (2018) found a similar conclusion, which is work-family conflict has a significant negative effect on job satisfaction towards academicians of private universities in Bangladesh.

\section{H2: Work-family conflict significantly influences employee performance.}

\section{G. The Influence of Religiosity on Employee performance}

In the theory of religiosity, it explained that religiosity is highly significant for the workers because if the workers have a high religiosity, then the motivation that the workers have to produce a good achievement or performance is also high (Hage \& Posner, 2015; Xia et al., 2021). The result of research proved that religiosity has a positive influence on performance (Adi \& Adawiyah, 2018; Onyemah, Rouziès, et al., 2018).

H3: Religiosity significantly influences employee performance.

\section{H. The Influence of Work-Family Conflict on Employee performance}

The concept of work-family conflict can be explained through the theory of roles. The main determinant of an individual's behavior is the expectation of behavior that people have. The result of research proved that workfamily conflict negatively affects employee performance (Adi \& Adawiyah, 2018). This result is also supported by the research done by Warokka \& Febrilia (2015) who found that work-family conflict has a negative influence on employee performance in Indonesia, and a similar result was also found by Derks et al. (2016) and Wang et al. (2019). Whereas, Soomro et al. (2018) found a different result where a work-family conflict has a positive influence on performance.

\section{H4: Work-family conflict significantly influences employee performance.}

\section{The Influence of Job Satisfaction on Employee performance}

One of the factors that influence performance in a public sector organization is the worker's job satisfaction. Job satisfaction is defined as a reaction and feeling of someone towards their workplace (Robbins \& Judge, 2019). Research done by Asbari et al. (2020b) proved that job satisfaction can improve employee performance. 
Likewise, previous researches found similar facts that job satisfaction has a positive influence on performance (Chummar et al., 2019; Inuwa, 2016; Kertiriasih et al., 2018).

H5: Job Satisfaction significantly influences employee performance.

\section{J. The Influence of Religiosity on Employee performance Through Job Satisfaction as Intervening Variable}

A worker can use religiosity that emphasized the logical thinking skills to find objective and accurate facts, as well as to predict risks, detect consequences from every decision so this will create satisfaction from themselves and performance will improve (Amaliah et al., 2015; Choy, 2020; Onyemah, Rouziès, et al., 2018). Research done by Wening \& Choerudin (2015) found a fact that religiosity has a significant influence on employee performance through job satisfaction as an intervening variable.

H6: Religiosity significantly influences employee performance through job satisfaction as an intervening variable.

\section{K. The Influence of Work-Family Conflict on Employee performance through Job Satisfaction as Intervening Variable}

According to the theory of roles, a work-family conflict is a form of conflict within roles when the role pressures from work and family are contradicting so participation in one of the roles is more difficult due to the participation of other roles. A research proved that there is a presence of negative relationships between workfamily conflict and job satisfaction that will have an impact on performance (Retnaningrum \& Al Musadieq, 2016). Likewise, research was done by Asbari et al. (2020b) mentioned that work-family conflict gives a significant influence on employee performance through job satisfaction as a mediating variable.

H7: Work-Family conflict significantly influences employee performance through job satisfaction as an intervening variable.

\section{Research Framework}

According to (Sekaran \& Bougie, 2003), the theoretical framework is a foundation on where every research project is based on. From the theoretical framework, a testable hypothesis can be formulated to find out whether a formulated theory is valid or non-valid. Then, this theory will be measured with appropriate statistical analysis. Referring to previous theory and research, there are relationships found between the variables consisting of religiosity, work-family conflict, job satisfaction, and employee performance. Religiosity refers to the research parameter of Ramlee et al. (2016), work-family conflict refers to the research parameter of (VU, 2020), job satisfaction refers to the research parameter of (G. S. Armstrong et al., 2015), while employee performance refers to the research parameter of (Dessler, 2006). The author built a research model as follows:

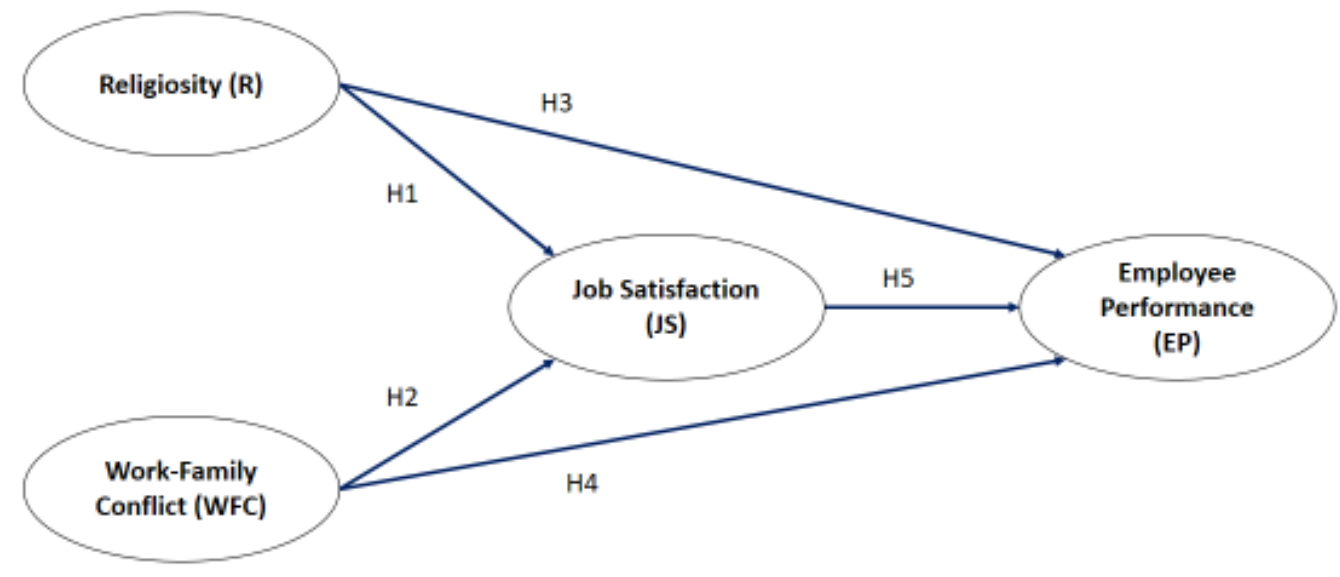

Figure 2. Research Model 


\section{METHOD OF RESEARCH}

\section{A. Definition of Operational Variable and Indicator}

The method used in this research is the quantitative method. Data collection is done by spreading questionnaires to every woman worker that has permanent working status in the manufacturing industry in Tangerang, Indonesia. The instrument used in measuring religiosity is adapted by the research of Ramlee et al. (2016) by using 5 items (R1-R5). The instrument of work-family conflict is adapted by the research of VU (2020) by using 5 items (WFC1-WFC5). The instrument of job satisfaction is adapted by the research of Armstrong et al. (2015) by using 5 items (JS1-JS5). Meanwhile, the instrument of employee performance is adapted by Dessler (2006) by using 15 items (EP1-EP15). The questionnaire is closely designed, except for the questions/statements concerning the respondent's identity, which is a semi-opened questionnaire. Every closed questions/statement, five answer options are given, which consist of: strongly agree (SA) with 5 scores, agree (A) with 4 scores, Neutral (N) with 3 scores, disagree (DA) with 2 scores, and strongly disagree (SDA) with 1 score. The method in data processing is by using PLS and SmartPLS 3.0 software as the tool.

Table 1. Variable and Items

\begin{tabular}{|c|c|c|c|}
\hline Variables & Items & Items Description & References \\
\hline \multirow[t]{4}{*}{ Religiosity } & R1 & $\begin{array}{l}\text { I strive to bring religious teachings to all of my business in } \\
\text { my life. }\end{array}$ & $\begin{array}{l}\text { Ramlee et al. } \\
(2016)\end{array}$ \\
\hline & R3 & $\begin{array}{l}\text { I strive to undergo my daily activities correspond to my own } \\
\text { belief. }\end{array}$ & \\
\hline & $\mathrm{R} 4$ & $\begin{array}{l}\text { I feel that my religion gives me comfort whenever I } \\
\text { struggle. }\end{array}$ & \\
\hline & R5 & $\begin{array}{l}\text { My religion is important because it answers my questions } \\
\text { about the meaning of life. }\end{array}$ & \\
\hline \multirow{3}{*}{$\begin{array}{l}\text { Work-Family } \\
\text { Conflict }\end{array}$} & WFC1 & My work demand disrupts my family life & VU (2020) \\
\hline & WFC2 & $\begin{array}{l}\text { High working hours make it difficult for me to fulfill my } \\
\text { responsibility in the household. }\end{array}$ & \\
\hline & WFC5 & $\begin{array}{l}\text { I have to make a change in my plans for family activities, } \\
\text { due to my work. }\end{array}$ & \\
\hline \multirow[t]{5}{*}{ Job Satisfaction } & JS1 & I feel pretty satisfied with my work now. & $\begin{array}{l}\text { Armstrong et al. } \\
(2015)\end{array}$ \\
\hline & JS2 & Almost every day, I feel enthusiastic about my work. & \\
\hline & JS3 & $\begin{array}{l}\text { I spent most of my time in my workplace as if this job is } \\
\text { never-ending. }\end{array}$ & \\
\hline & JS4 & I enjoy my job in the workplace. & \\
\hline & JS5 & I consider my job as a kind of unpleasant. & \\
\hline \multirow{8}{*}{$\begin{array}{l}\text { Employee } \\
\text { Performance }\end{array}$} & EP6 & My skill of finishing working overtime is outstanding & \\
\hline & EP7 & The knowledge that I have about my work is outstanding & \\
\hline & EP8 & The information that I have to finish my work is excellent. & \\
\hline & EP9 & I am capable to understand the work that is given. & \\
\hline & EP10 & My boss thinks that I am trustworthy. & \\
\hline & EP11 & I am responsible for the work that I should finish. & \\
\hline & EP12 & I am always on time in terms of attendance. & \\
\hline & EP13 & My dismissal time is always on schedule. & \\
\hline
\end{tabular}




\section{B. Population and Sample}

The population in this research is the workers working in the manufacturing industry in Tangerang, Indonesia that consists of 171 workers. The questionnaire is given by a simple random sampling method. The questionnaire that was returned and valid as many as 120 samples ( $70.2 \%$ from the whole population)

\section{RESULTS AND DISCUSSION}

\section{A. Sample Description}

Tabel 2. Descriptive Sample Information

\begin{tabular}{llll}
\hline Criteria & & Total & \% \\
\hline Gender & Male & 79 & $66 \%$ \\
& Female & 41 & $34 \%$ \\
\hline Age (per December 2020) & $<30$ years old & 90 & $75 \%$ \\
& $30-40$ years old & 19 & $167 \%$ \\
& $>40$ years old & 11 & $9 \%$ \\
\hline Years of Service & $<5$ years & 86 & $72 \%$ \\
& $5-10$ years & 30 & $25 \%$ \\
& $>10$ years & 4 & $3 \%$ \\
\hline Highest Education/Degree & $\geq$ bachelor degree & 26 & $22 \%$ \\
& $=$ secondary high & 93 & $77 \%$ \\
& $<$ secondary high & 1 & $1 \%$ \\
\hline
\end{tabular}

\section{B. Results for Validity Test and Research Indicator Reliability}

Stages of measuring on testing model involve convergent validity test and discriminant validity. While the value of Cronbach's alpha and composite reliability is needed in testing for construction reliability. PLS analysis results could be used to test for research hypothesis if all indicators in the PLS model have met the requirements of convergent validity, discriminant validity, and reliability test.

\section{Convergent Validity Test}

According to the results from SmartPLS 3.0, after taking out the items that do not meet the terms and conditions, thus in Table 3, all indicators have a loading factor above 0.7 . Therefore, convergent validity from this research model has met all of the requirements. Loading factor, Cronbach's alpha, composite reliability, and AVE in every construct can be seen in Table 3 below: 


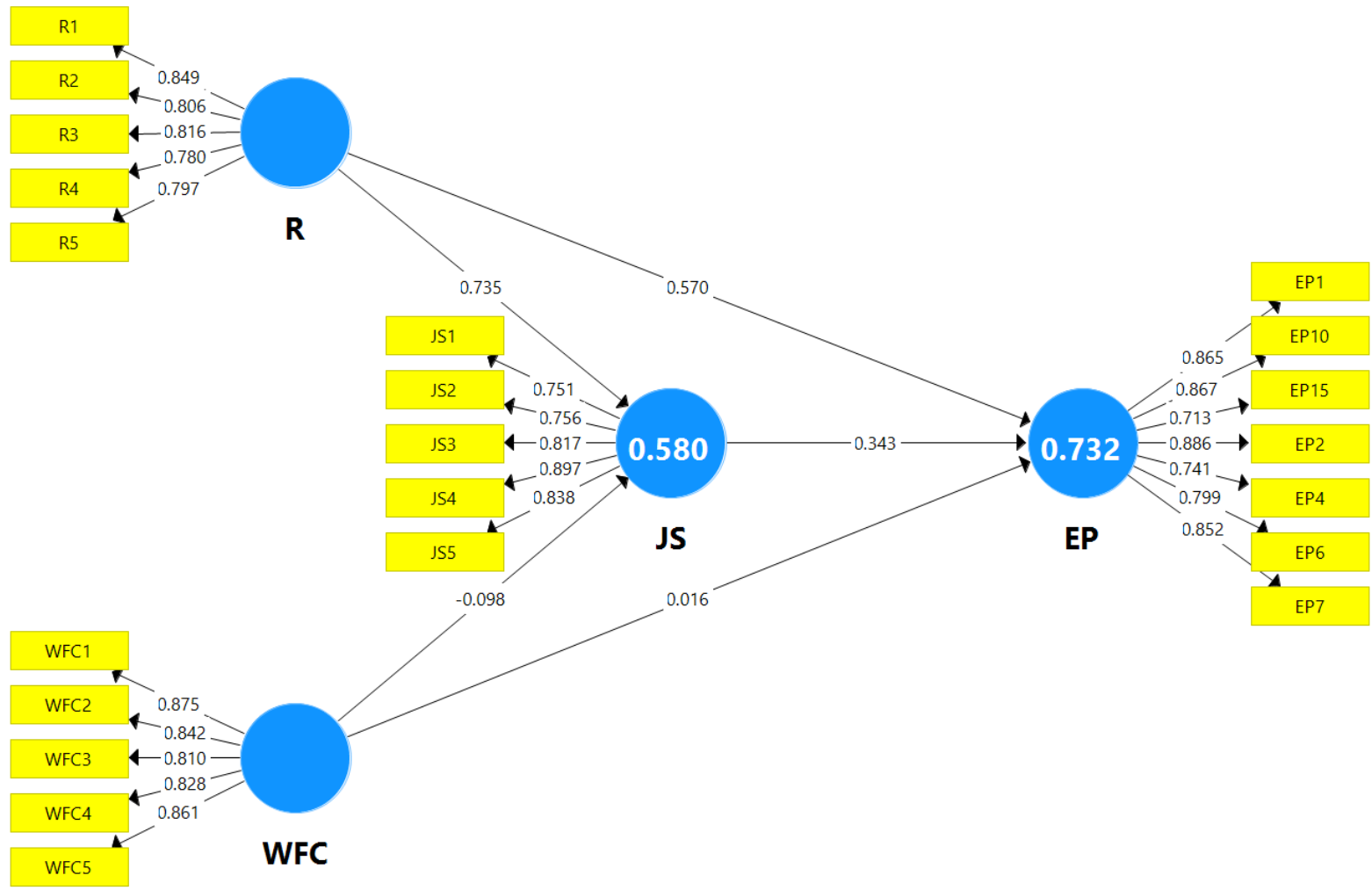

Figure 2. Research Model Fit

Tabel 3. Items Loadings, Cronbach's Alpha, Composite Reliability, and Average Variance Extracted (AVE)

\begin{tabular}{|c|c|c|c|c|c|}
\hline Variables & Items & Loadings & $\begin{array}{l}\text { Cronbach's } \\
\text { Alpha }\end{array}$ & $\begin{array}{l}\text { Composite } \\
\text { Reliability }\end{array}$ & AVE \\
\hline \multirow{5}{*}{ Religiosity (R) } & $\mathrm{R} 1$ & 0.849 & 0.869 & 0.905 & 0.656 \\
\hline & R2 & 0.806 & & & \\
\hline & R3 & 0.816 & & & \\
\hline & $\mathrm{R} 4$ & 0.780 & & & \\
\hline & R5 & 0.797 & & & \\
\hline \multirow{5}{*}{$\begin{array}{l}\text { Work-Family Conflict } \\
\text { (WFC) }\end{array}$} & WFC1 & 0.875 & 0.899 & 0.925 & 0.712 \\
\hline & WFC2 & 0.842 & & & \\
\hline & WFC3 & 0.810 & & & \\
\hline & WFC4 & 0.828 & & & \\
\hline & WFC5 & 0.861 & & & \\
\hline \multirow{5}{*}{$\begin{array}{l}\text { Job Satisfaction } \\
\text { (JS) }\end{array}$} & JS1 & 0.751 & 0.872 & 0.907 & 0.662 \\
\hline & JS2 & 0.756 & & & \\
\hline & JS3 & 0.817 & & & \\
\hline & JS4 & 0.897 & & & \\
\hline & JS5 & 0.838 & & & \\
\hline \multirow{7}{*}{$\begin{array}{l}\text { Employee Performance } \\
\text { (EP) }\end{array}$} & EP1 & 0.865 & 0.917 & 0.935 & 0.672 \\
\hline & EP2 & 0.886 & & & \\
\hline & EP4 & 0.741 & & & \\
\hline & EP6 & 0.799 & & & \\
\hline & EP7 & 0.852 & & & \\
\hline & EP10 & 0.867 & & & \\
\hline & EP15 & 0.713 & & & \\
\hline
\end{tabular}




\section{Discriminant Validity Test}

Discriminant validity is done to ensure that every concept of each latent variable is in contrast with the other latent variables. A model has a good discriminant validity if the quadratic value of AVE in each exogenous construct (value on the diagonal) exceeds the correlation between the construct with the other construct (value below diagonal) (Ghozali, 2014). The result of discriminant validity testing is done by the quadratic value of AVE, which means by seeing the Fornell-Larcker Criterion Value that is obtained the same way as shown below:

Table 4. Discriminant Validity

\begin{tabular}{cllll}
\hline Variables & EP & JS & R & WFC \\
\hline EP & $\mathbf{0 . 8 2 0}$ & & & \\
JS & 0.770 & $\mathbf{0 . 8 1 3}$ & & \\
R & 0.806 & 0.756 & $\mathbf{0 . 8 1 0}$ & \\
WFC & -0.192 & -0.254 & -0.212 & $\mathbf{0 . 8 4 4}$ \\
& & & & \\
\hline
\end{tabular}

The discriminant validity test results shown in Table 4 above indicates the whole construct having a square root value of AVE above correlation value with the other latent construct, through Fornell-Larcker Criterion, so it can be concluded that a model has met a discriminant validity (Fornell \& Larcker, 1981).

Next, an evaluation of collinearity is done to find out whether there is collinearity in the model. To find collinearity, calculation of VIF id is needed in every construct. If the VIF value is above 5, then the collinearity is present in the model (Hair et al., 2014). As shown in Table 5, all VIF value is lower than 5, which means that the model has no issue with collinearity.

Table 5. Collinearity Statistics (VIF)

\begin{tabular}{cllll}
\hline Variables & EP & JS & R & WFC \\
\hline EP & & & \\
JS & 2.382 & & \\
R & 2.334 & 1.047 & \\
WFC & 1.070 & 1.047 & \\
\end{tabular}

\section{Construct Reliability Test}

Construct reliability can be assessed from the value of Cronbach's alpha and composite reliability from each construct. The value of composite reliability and Cronbach's alpha is suggested to be more than 0.7 (Ghozali, 2014). Reliability test results in Table 3 above show that all construct has composite reliability value and Cronbach's alpha value higher than $0.7(>0.7)$. In conclusion, all construct has met the reliability that is required.

\section{Hypothesis Examination}

The hypothesis test in PLS is also denoted as an inner model test. This test covers a significance test that has a direct and indirect impact as well as how large is the measurement of the exogenous variable impact towards the endogenous variable. To discover the effect of the research variable, it needs a direct and moderation impact test. The impact test is done by using a t-Statistic test in an analysis model called Partial Least Squared (PLS) with the help of SmartPLS 3.0 software. With the bootstrapping method, R square value and significance test value can be obtained as shown in the table below: 
Tabel 6. $R$ Square Value

\begin{tabular}{lll}
\hline & R Square & R Square Adjusted \\
\hline EP & 0.732 & 0.725 \\
JS & 0.580 & 0.573 \\
\hline
\end{tabular}

Table 7. Hypotheses Testing

\begin{tabular}{llccccc}
\hline Hypotheses & Relationship & Beta & SE & T Statistics & P-Values & Decision \\
\hline H1 & R -> JS & 0.735 & 0.046 & 16.041 & 0.000 & Supported \\
H2 & WFC -> JS & -0.098 & 0.049 & 2.016 & 0.044 & Supported \\
H3 & R -> EP & 0.570 & 0.069 & 8.297 & 0.000 & Supported \\
H4 & WFC -> EP & 0.016 & 0.039 & 0.413 & 0.680 & $\begin{array}{l}\text { Not } \\
\text { Supported }\end{array}$ \\
H5 & JS -> EP & 0.343 & 0.073 & 4.732 & 0.000 & Supported \\
H6 & R -> JS -> EP & 0.252 & 0.055 & 4.574 & 0.000 & Supported \\
H7 & & & & & \\
& WFC -> JS -> EP & -0.034 & 0.021 & 1.614 & 0.107 & $\begin{array}{l}\text { Not } \\
\text { Supported }\end{array}$ \\
\hline
\end{tabular}

Based on Table 5 above, the $R$ Square value for JS is 0.580 , which means the Job Satisfaction (JS) variable can be explained by Religiosity (R) and Work-Family Conflict (WFC) variable that has the value of $58.0 \%$, while the remaining $42.0 \%$ is explained by other variables not discussed in this research. $R$ Square value of EP is 0.732, which means the Employee Performance (EP) variable can be explained by the Religiosity (R), WorkFamily Conflict (WFC), and Job Satisfaction (JS) variables that have the percentage of $73.2 \%$, while the remaining $26.8 \%$ is explained by other variables not discussed in this research. Meanwhile, Table 7 shows $T$ Statistics and $P$-Values that explain the influence within variables of research mentioned.

\section{Discussion}

\section{The Influence of Religiosity Towards Worker's Job Satisfaction}

Religiosity construct has a positive influence on the construct of job satisfaction, this case is proven by the original sample value (Beta) in the value of 0.735 , which means there is a positive relationship between the construct. The T-Statistics value of this constructed relationship is 16.041 with the $\mathrm{T}$ value of 1.96 at a significance level of $5 \%$ because the criteria for this T-statistics value should be $>1.96$ and P-Value $0,000<0,05$, hence the calculation result above shows that the relationship between religiosity and job satisfaction is considered to be significant. Therefore, religiosity has a positive influence on the job satisfaction construct, so the first hypothesis (H1) is accepted. This result corresponds to the research that proves religiosity positively influences worker's job satisfaction (Zahrah, Abdul Hamid, Abdul Rani, et al., 2016:195-198; Zotti et al, 2016:1-19). The presence of religiosity will still have an influence that surely supports the optimality of worker's job satisfaction. The enhancement of religiosity within the workers through the holding of religious 
studies, social services, and other activities could increase the worker's knowledge about religion and their sensitivity to practicing religious teachings in daily life. Therefore, positive values of religiosity will develop and influence the behavior of the workers.

\section{The Influence of Work-Family Conflict Towards Worker's Job Satisfaction}

The construct of work-family conflict has a negative influence on the construct of job satisfaction. This is proven by the original sample value $($ Beta) in the value of $-0,098$, which means there is a negative relationship between the construct. The T-Statistics value of this constructed relationship is 2.016 with the T value of 1.96 at a significance level of $5 \%$ because the criteria for this T-statistics value should be $>1.96$ and P-Value $0,000<0,05$, hence the calculation result above shows that the relationship between work-family conflict and job satisfaction is considered to be significant. Therefore, the work-family conflict has a negative influence on the job satisfaction construct, so the second hypothesis (H2) is accepted. This result corresponds to the research that proves work-family conflict negatively influences job satisfaction (Martinez-Sanchez et al., 2018: 268-394; Thi et al., 2016:63- 72; Mihelic, 2014: 446-466). Work-family conflict will hurt worker's job satisfaction. To solve this kind of problem, a family-friendly management policy program is needed. One of the ways is to give a flexible, and job-sharing time policy. The flexible time or flexible working hours enable the workers to choose when they want to work and when they can have optimal time for their family, or even to do their family responsibility (Martinez-Sanchez et al., 2018: 268-394; Thi et al., 2016:63-72; Mihelic, 2014: 446-466).

\section{The Influence of Religiosity Towards Employee performance}

Religiosity construct has a positive influence on the construct of performance, this case is proven by the original sample value (Beta) in the value of 0.570 , which means there is a positive relationship between the construct. The T-Statistics value of this constructed relationship is 8.297 with the T value of 1.96 at a significance level of $5 \%$ because the criteria for this T-statistics value should be $>1.96$ and P-Value $0,000<0,05$, hence the calculation result above shows that the relationship between religiosity and performance is considered to be significant. Therefore, religiosity has a positive influence on performance construct, so the third hypothesis (H3) is accepted. This result corresponds to some researches that prove religiosity is positively influenced performance (Wening \& Choerudin, 2015:181-191); Zahrah, Norasyikin, Abdul, et al. 2016: 195-198; Osman-Gani et al. 2012: 360376). To make a good performance, the company's management should maintain and prepare more on the framework with the religiosity practices. The presence of religiosity would still have an influence that surely supports the optimality of employee performance. A good attitude of religiosity could be the basis of doing business activities oriented to the results. Therefore, a strategy in the company to improve the values of religiosity is needed. For example, by giving space and time to the marketing labor to carry out religious rituals, providing an adequate place to pray in each marketing offices for the Muslims, giving chance for the people to pray, preventing people to do work or other activities in any religious celebration, as well as celebrating together in any major religious ceremony.

\section{The Influence of Work-Family Conflict Towards Employee performance}

The construct of work-family conflict does not have any significant influence on the construct of employee performance, where this is proven by the original sample value (Beta) in the value of 0.016, which means there is a very low relationship between the two constructs. The T-Statistics value of this constructed relationship is 0.413 with the $\mathrm{T}$ value of 1.96 at a significance level of $5 \%$ because the $T$-Statistics value is below 1.96 and the $P$-Value 0.680 , which is above 0.05 , so the influence of work-family conflict towards performance is considered to be insignificant. Therefore, the fourth hypothesis (H4) is rejected. There is a slight difference with the research result of Adi \& Adawiyah, 2018 dan Zain \& Setiawati, 2017 who found a fact that work-family conflict has a negative influence on employee performance.

\section{The Influence of Job Satisfaction Towards Employee performance}

The construct of job satisfaction has a positive influence on the construct of employee performance. This is proven by the original sample value (beta) in the value of 0.343 , which means there is a positive relationship between the two constructs. The T-Statistics value of this constructed relationship is 4.732 with the $\mathrm{T}$ value of 1.96 at the significance level of $5 \%$ because the criteria for this T-statistics value should be $>1.96$ and P-Value $0,000<0,05$, hence the calculation result above shows that the relationship between job satisfaction and 
performance is considered to be significant. Therefore, job satisfaction has a positive influence on performance construct, so the fifth hypothesis (H5) is accepted. Worker's job satisfaction can be known after a worker has done their job. In other words, a worker's job satisfaction refers to the after-employment evaluation or the result of evaluation after comparing the things achieved in their work with the worker's expectations. This concludes that worker's job satisfaction is the outcome felt due to their work results, which can be similar or more than what they have expected. From this satisfaction limit, an organization should be able to identify and try to find out the things expected from the workers based on their work results. Worker's expectations can be identified appropriately if the leader could understand the worker's perceptions about satisfaction. Understanding a worker's perception towards satisfaction is important, so the perception gap between the leader and the worker would not occur in a workplace (Handayani \& Suhartini, 2005:38-39). This result corresponds to some of the researches that prove job satisfaction could improve employee performance (Siengthai \& Pila-ngarm, 2016: 162-180; Gu \& Chi Sen Siu, 2009: 561-578; Onyebu \& Otomayi, 2017: 48-60). When the level of satisfaction of a worker degrades, then it is advisable to do an evaluation as well as counseling, so a worker's job satisfaction would increase and receive achievements as a return for the worker's effort, such as experiencing in higher positions, giving bonuses or gifts to the workers with the expectation that the workers will improve their spirit when working so job satisfaction is formed and performance will also be enhanced.

\section{The Influence of Religiosity Towards Employee performance Through Job Satisfaction as Intervening Variable}

The result from Table 7, was found that religiosity influences employee performance in the Beta value of 0.570 , with a T-statistics value of 8.297>1.96. Religiosity influences job satisfaction with the Beta value of 0.735 , with a $T$-statistics value of $16.041>1.96$. Job satisfaction has a significant positive influence on employee performance with a Beta value of 0.343 and a T-statistics value of $4.732>1.96$. Therefore, the influence of religiosity on employee performance through job satisfaction has a value of $0.252(0.735 \times 0.343=0.252)$. Based on the PLS analysis result, the sixth hypothesis states that religiosity influences employee performance through job satisfaction as moderating/intervening variable. This shows that H6 is accepted. Overall, religiosity is at a very good level, but a little improvement is still needed to maintain and enhance the existing religiosity to the workers through religious teachings, social services, and other activities that could increase the knowledge of religion and sensitivity in practicing the teachings in daily basis, so positive values of religiosity could develop and influence the worker's behavior that consists of performance and job satisfaction.

\section{The Influence of Work-Family Conflict Towards Employee performance through Job Satisfaction as Intervening Variable}

Based on the analysis from Table 7 , it was found that work-family conflict does not have any significant influence on employee performance, since the Beta value is only 0.016 and the T-statistics value of $0.413<1.96$ (conclusion: insignificant). Work-family conflict has a significant negative influence on job satisfaction with the Beta value of -0.049 and T-statistics value of $2.016>1.96$. Job satisfaction has a significant positive influence on employee performance with a Beta value of 0.343 and a T-statistics value of $4.732>1.96$. Therefore, the influence of work-family conflict on employee performance through job satisfaction has a value of -0.034 ($0.098 \times 0.343=-0.034)$. Based on the PLS analysis result, work-family conflict does not significantly influence employee performance through job satisfaction as a mediating/intervening variable. This means that the seventh hypothesis (H7) is rejected. The changes and problems of the organization are demanding the company to adopt more of the policies related to work and family. A company should give more and deeper attention to solving work-family conflict because it will affect the work outcome, such as performance and job satisfaction. The impact of degrading performance and job satisfaction is it could cause disadvantages either for workers or for the company, so a family-friendly policy is needed for worker's job satisfaction.

\section{CONCLUSION AND SUGGESTION}

\section{A. Conclusion}

Based on the analysis result and the discussion regarding the influence of work-family conflict and religiosity towards employee performance and job satisfaction as an intervening variable in the manufacturing industry, it can be concluded as follows: (1) Religiosity is significantly influenced job satisfaction, (2) Work-family conflict has significant negative influence towards job satisfaction, (3) Religiosity has significant positive influence towards employee performance, (4) work-family conflict does not significantly influence employee performance, 
(5) job satisfaction has significant positive influence towards employee performance, (6) religiosity has significant positive influence towards employee performance through job satisfaction as intervening variable, (7) work-family conflict does not significantly influence employee performance through job satisfaction as intervening variable.

\section{B. Suggestion}

The manufacturing industry needs to improve its family-friendly policy and corresponds to the religious values of the workers. Besides that, management should maintain and need to prepare more on the framework that is in tune with the religious practices in a workplace. Lastly, a company's management should keep on evaluating the employee performance that could finally be appropriate in receiving the award as a return for their efforts.

\section{REFERENCES}

[1] Adi, P. H., \& Adawiyah, W. R. (2018). The impact of religiosity, environmental marketing orientation and practices on performance. Journal of Islamic Marketing.

[2] Amaliah, I., Aspiranti, T., \& Purnamasari, P. (2015). The Impact of the Values of Islamic Religiosity to Islamic Job Satisfaction in Tasikmalaya West Java, Indonesia, Industrial Centre. Procedia-Social and Behavioral Sciences, 211, 984-991.

[3] Aman, J., Abbas, J., Nurunnabi, M., \& Bano, S. (2019). The relationship of religiosity and marital satisfaction: The role of religious commitment and practices on marital satisfaction among Pakistani respondents. Behavioral Sciences, 9(3), 1-13. https://doi.org/10.3390/bs9030030

[4] Aminiar, C., Novitasari, D., \& Asbari, M. (2020). Analysis on Financial Performance Using Du Pont System Method at PT Indofood Sukses Makmur Tbk Period Year 2015-2019. Journal of Industrial Engineering \& Management Research (JIEMAR), 1(3), $122-134$. https://doi.org/https://doi.org/10.7777/jiemar.v1i2

[5] Armstrong, G. S., Atkin-plunk, C. A., \& Wells, J. (2015). The Relationship between Work-Family Conflict, Correctional Officer Job Stress, and Job Satisfaction. International Association for Correctional and Forensic Psychology, XX(X), 1-17. https://doi.org/10.1177/0093854815582221

[6] Armstrong, M., \& Taylor, S. (2014). Human Resource Management Practice. Ashford Colour Press Ltd.

[7] Asbari, M., Bernarto, I., Pramono, R., Purwanto, A., Hidayat, D., Sopa, A., Alamsyah, V. U., Senjaya, P., Fayzhall, M., \& Mustofa. (2020a). The effect of work-family conflict on job satisfaction and performance: A study of Indonesian female employees. International Journal of Advanced Science and Technology, 29(3), 6724-6748.

[8] Asbari, M., Bernarto, I., Pramono, R., Purwanto, A., Hidayat, D., Sopa, A., Alamsyah, V. U., Senjaya, P., Fayzhall, M., \& Mustofa. (2020b). The effect of work-family conflict on job satisfaction and performance: A study of Indonesian female employees. International Journal of Advanced Science and Technology, 29(3), 6724-6748. http://sersc.org/journals/index.php/IJAST/article/view/7325

[9] Babin, B. J., \& Boles, J. S. (1998). Employee behavior in a service environment: A model and test of potential differences between men and women. Journal of Marketing, 62(2), 77-91. https://doi.org/10.2307/1252162

[10] Baluyos, G. R., Rivera, H. L., \& Baluyos, E. L. (2019). Teachers' Job Satisfaction and Work Performance. Open Journal of Social Sciences, 07(08), 206-221. https://doi.org/10.4236/jss.2019.78015

[11] Basuki, S., Novitasari, D., Fahlevi, M., Nadeak, M., Fahmi, K., Pebrina, E. T., Sudiyono, R. N., \& Asbari, M. (2020). Performance Analysis of Female Employees in the Covid-19 Pandemic Period: The Effects of Readiness for Change and Effectiveness of $\begin{array}{lllll}\text { Transformational State } & \text { Leadership. } & \text { Solid } & \text { 63(1s), }\end{array}$ http://www.solidstatetechnology.us/index.php/JSST/article/view/709

[12] Bednarczuk, M. (2019). God in the workplace: Religiosity and job satisfaction among US public servants. Journal of Public and Nonprofit Affairs, 5(3), 261-276.

[13] Bernardin, H., \& Russel, J. (1993). Human Resource Management: An Experimental Approach. Mc Graw Hill Companies.

[14] Bogler, R. (2001). The influence of leadership style on teacher job satisfaction. Educational Administration Quarterly, 37(5), 662683. https://doi.org/10.1177/00131610121969460

[15] Charan, I. A., Xin, S., Zezhuang, W., \& Yao, D. (2020). Rethinking efficacy: People's perception of ritual healing and trance religious practices at shrines in Pakistan. Asian Journal of Psychiatry, 52, 102020. https://doi.org/https://doi.org/10.1016/j.ajp.2020.102020

[16] Chin, W. (1998). The Partial Least Squares Approach to Structural Equation Modeling (E. Modern Methods for Business Research, In: G. A. Marcoulides (ed.)). Lawrence Erlbaum Associates Publisher. 
[17] Chordiya, R., Sabharwal, M., \& Goodman, D. (2017). Affective Organizational Commitment and Job Satisfaction: a Cross-National Comparative Study. Public Administration, 95(1), 178-195. https://doi.org/10.1111/padm.12306

[18] Choy, J. P. (2020). Religious rules as a means of strengthening family ties: Theory and evidence from the Amish. Journal of Comparative Economics, 48(3), 729-748. https://doi.org/https://doi.org/10.1016/j.jce.2019.12.007

[19] Chummar, S., Singh, P., \& Ezzedeen, S. R. (2019). Exploring the differential impact of work passion on life satisfaction and job performance via the work-family interface. Personnel Review, 48(5), 1100-1119. https://doi.org/10.1108/PR-02-2017-0033

[20] Cohen, A. B., Mazza, G. L., Johnson, K. A., Enders, C. K., Warner, C. M., Pasek, M. H., \& Cook, J. E. (2017). Theorizing and measuring religiosity across cultures. Personality and Social Psychology Bulletin, 43(12), 1724-1736.

[21] Darto, M., Setyadi, D., Riadi, S. S., \& Hariyadi, S. (2015). The effect of transformational leadership, religiosity, job satisfaction, and organizational culture on organizational citizenship behavior and employee performance in the regional offices of national in stitute of public administration, Republic of Indonesia. European Journal of Business and Management, 7(23), 205-219.

[22] Derks, D., Bakker, A. B., Peters, P., \& van Wingerden, P. (2016). Work-related smartphone use, work-family conflict and family role performance: The role of segmentation preference. Human Relations, 69(5), 1045-1068.

[23] Dessler, G. (2006). Manajemen Sumber Daya Manusia (10th ed.). Indeks Kelompok Gramedia.

[24] Eliyana, A., Ma'arif, S., \& Muzakki. (2019). Job satisfaction and organizational commitment effect in the transformational leadership towards employee performance. European Research on Management and Business Economics, 25(3), 144-150. https://doi.org/10.1016/j.iedeen.2019.05.001

[25] Fornell, C., \& Larcker, D. F. (1981). Evaluating Structural Equation Models with Unobservable Variables and Measurement Error. Journal of Marketing Research, 18(1), 39. https://doi.org/10.2307/3151312

[26] Ghozali, I. (2014). Structural Equation Modeling, Metode Alternatif dengan Partial Least Square (PLS) (4th ed.). Badan Penerbit Universitas Diponegoro.

[27] Goestjahjanti, S. F., Novitasari, D., Hutagalung, D., Asbari, M., \& Supono, J. (2020). Impact of Talent Management, Authentic Leadership and Employee Engagement on Job Satisfaction: Evidence From South East Asian Industries. Journal of Critical Reviews, 7(19), 67-88. http://www.jcreview.com/?mno=101983

[28] Greenhaus, J. H., \& Beutell, N. J. (1985). Sources of Conflict Between Work and Family Roles. Academy of Management Review, 10(1), 76-88. https://doi.org/https://doi.org/10.5465/amr.1985.4277352

[29] Hage, J., \& Posner, B. Z. (2015). Religion, religiosity, and leadership practices. Leadership \& Organization Development Journal.

[30] Hair, J. F., Black, W. C., Babin, B. J., \& Anderson, R. E. (2010). Multivariate Data Analysis (7th ed.). Pearson Prentice Hall.

[31] Hair, J. F., Hult, G. T., Ringle, C. M., \& Sarstedt, M. (2014). A primer partial least squaresstructural equation modeling (PLS-SEM). SAGE Publications.

[32] Hedayat, A., Sogolitappeh, F. N., Shakeri, R., Abasifard, M., \& Khaledian, M. (2018). Relationship between Organizational Commitment and Job Satisfaction. International Letters of Social and Humanistic Sciences, 81, 30-38. https://doi.org/10.18052/www.scipress.com/ilshs.81.30

[33] Hichy, Z., Sciacca, F., Marco, G. Di, \& Pasquale, C. De. (2020). Heliyon Effects of religious orientation and state secularism on preimplantation genetic diagnosis. Heliyon, 6(May), e04798. https://doi.org/10.1016/j.heliyon.2020.e04798

[34] Hutagalung, D., Asbari, M., Fayzhall, M., Ariyanto, E., Agistiawati, E., Sudiyono, R. N., Waruwu, H., Goestjahjanti, F. S., Winanti, \& Yuwono, T. (2020). Peran Religiusitas, Kepemimpinan Transformasional, Kepuasan Kerja dan Mediasi Organizational Citizenship Behavior terhadap Kinerja Guru. EduPsyCouns: Journal of Education, Psychology and Counseling, 2(1), 311-326. https://ummaspul.e-journal.id/Edupsycouns/article/view/483

[35] Hutagalung, D., Sopa, A., Asbari, M., Cahyono, Y., Maesaroh, S., \& Chidir, G. (2020). Influence of Soft Skills, Hard Skills and Organization Learning on Teachers' Performance through Innovation Capability as Mediator. Journal of Critical Reviews, 7(19), 5466. http://www.jcreview.com/?mno=101978

[36] Inuwa, M. (2016). Job Satisfaction and Employee Performance: An Empirical Approach. The Millennium University Journal, 1(1), $90-103$.

[37] Jiménez, A., Jiang, G. F., Petersen, B., \& Gammelgaard, J. (2019). Within-country religious diversity and the performance of private participation infrastructure projects. Journal of Business Research, 95, 13-25. https://doi.org/https://doi.org/10.1016/j.jbusres.2018.08.027

[38] Jumiran, Novitasari, D., Nugroho, Y. A., Sutardi, D., Sasono, I., \& Asbari, M. (2020). Pengaruh Dimensi Kepemimpinan Transformasional terhadap Kepuasan Kerja dan Komitmen Organisasional: Studi Kasus pada Dosen Perguruan Tinggi Swasta. EduPsyCouns: Journal of Education, Psychology and Counseling, 2(1), 600-621. https://ummaspul.ejournal.id/Edupsycouns/article/view/555 
[39] Kamar, K., Novitasari, N., Asbari, M., Winanti, \& Goestjahjanti, F. S. (2019). Enhancing Employee Performance during the Covid19 Pandemic: the Role of Readiness for Change Mentality. Jurnal Dinamika Manajemen, 11(2), 154-166. http://journal.unnes.ac.id/nju/index.php/jdm/article/view/25279

[40] Kertiriasih, N. N. R., Sujana, I. W., \& Suardika, I. N. (2018). The Effect of Leadership Style to Job Satisfaction, Employee Engagement and Employee Performance (Study at PT. Interbat, Bali, Nusra, and Ambon). International Journal of Contemporary Research and Review, 9(03), 20592-20600. https://doi.org/10.15520/ijcrr/2018/9/03/468

[41] Koenig, H. G., Al Zaben, F., Khalifa, D. A., \& Al Shohaib, S. (2015). Measures of religiosity. In Measures of personality and social psychological constructs (pp. 530-561). Elsevier.

[42] Lestari, B., Novitasari, D., Silitonga, N., \& Asbari, M. (2020). The Effect of Recruitment and Career Development on The Spirit of Teachers' Work Performance in MTs Nurul Huda. Journal of Industrial Engineering \& Management Research (JIEMAR), 1(2), 108-121. https://doi.org/https://doi.org/10.7777/jiemar.v1i2

[43] Luthans, F. (2005). Perilaku Organisasi (11th ed.). Penerbit ANDI.

[44] Maesaroh, S., Asbari, M., Hutagalung, D., Agistiawati, E., Basuki, S., Radita, F. R., Nurasiah, Yulia, Y., Singgih, E., \& Chidir, G (2020). Pengaruh Religiusitas dan Kepemimpinan Transformasional terhadap Kinerja Guru melalui Mediasi Organizational Citizenship Behavior. EduPsyCouns: Journal of Education, Psychology and Counseling, 2(1), 276-290. https://ummaspul.ejournal.id/Edupsycouns/article/view/473

[45] Martinez-Sanchez, A., Perez-Perez, M., Vela-Jimenez, M.-J., \& Abella-Garces, S. (2018). Job satisfaction and work-family policies through work-family enrichment. Journal of Managerial Psychology.

[46] Mathis, \& Jackson. (2002). Manajemen Sumber Daya Manusia (Pertama). Salemba Empat.

[47] Novitasari, D., Asbari, M., Wijaya, M. R., \& Yuwono, T. (2020). Effect of Organizational Justice on Organizational Commitment: Mediating Role of Intrinsic and Extrinsic Satisfaction. International Journal of Science and Management Studies (IJSMS), 3(3), 96112. http://www.ijsmsjournal.org/volume3-issue3.html

[48] Novitasari, D., Sasono, I., \& Asbari, M. (2020). Work-Family Conflict and Employee performance during Covid-19 Pandemic: What is the Role of Readiness to Change Mentality? International Journal of Science and Management Studies (IJSMS), 3(4), $122-134$. http://www.ijsmsjournal.org/volume3-issue4.html

[49] Nuryanti, Y., Novitasari, D., Nugroho, Y. A., Fauji, A., Gazali, \& Asbari, M. (2020). Meningkatkan Komitmen Organisasional Dosen: Analisis Pengaruh Kepemimpinan Perguruan Tinggi dan Kepuasan Intrinsik \& Ekstrinsik Dosen. EduPsyCouns: Journal of Education, Psychology and Counseling, 2(1), 561-581. https://ummaspul.e-journal.id/Edupsycouns/article/view/551

[50] Onyemah, V., Rouzie, D., \& Iacobucci, D. (2018). Impact of religiosity and culture on salesperson job satisfaction and performance. International Journal of Cross Cultural Management, 18(2), 191-219. https://doi.org/10.1177/1470595818787543

[51] Qureshi, M. A., Qureshi, J. A., Thebo, J. A., Shaikh, G. M., Brohi, N. A., \& Qaiser, S. (2019). The nexus of employee's commitment, job satisfaction, and job performance: An analysis of FMCG industries of Pakistan. Cogent Business and Management, 6(1). https://doi.org/10.1080/23311975.2019.1654189

[52] Rahman, M. M., Abdul, M., Mansor, Z. D., Ali, N. A., Samuel, A. B., Uddin, M. J., Ogiri, I., \& Rahaman, M. S. (2018). Effect of work-family conflict on job satisfaction of academicians of private universities in Bangladesh: a structural equation modeling approach. Journal of Advanced Research in Social and Behavioral Sciences, 10(1), 1-8.

[53] Ramlee, N., Osman, A., Salahudin, S. N., Yeng, S. K., Ling, S. C., \& Safizal, M. (2016). The Influence of Religiosity, Stress and Job Attitude towards Organizational Behavior: Evidence from Public Universities in Malaysia. Procedia Economics and Finance, 35(October 2015), 563-573. https://doi.org/10.1016/s2212-5671(16)00069-1

[54] Retnaningrum, A. K., \& Al Musadieq, M. (2016). Pengaruh Work-Family Conflict Terhadap Kepuasan Kerja dan Kinerja (Studi pada perawat wanita RSUD Wonosari Yogyakarta). Jurnal Administrasi Bisnis, 36(1), 72-81.

[55] Robbins, S. P., \& Judge, T. A. (2019). Organizational behavior. pearson.

[56] Rowatt, W. C., \& Al-Kire, R. L. (2021). Dimensions of religiousness and their connection to racial, ethnic, and atheist prejudices. Current Opinion in Psychology, 40, 86-91. https://doi.org/https://doi.org/10.1016/j.copsyc.2020.08.022

[57] Sabahi, A. H., \& Sanai Dashti, N. (2016). The effect of emotional intelligence and job satisfaction on organizational citizen ship behavior. Management Science Letters, 64(2003), 475-480. https://doi.org/10.5267/j.ms1.2016.6.001

[58] Sekaran, U., \& Bougie, R. (2003). Research Methods For Business: A Skill Building Approach (Sixth edit). John Wiley and Sons, Inc.

[59] Silitonga, N., Novitasari, D., Sutardi, D., Sopa, A., Asbari, M., Yulia, Y., Supono, J., \& Fauji, A. (2020). The Relationship of Transformational Leadership, Organizational Justice and Organizational Commitment: a Mediation Effect of Job Satisfaction. Journal of Critical Reviews, 7(19), 89-108. http://www.jcreview.com/?mno=101999 
[60] Soomro, A. A., Breitenecker, R. J., \& Shah, S. A. M. (2018). Relation of work-life balance, work-family conflict, and family-work conflict with the employee performance-moderating role of job satisfaction. South Asian Journal of Business Studies.

[61] Sudiyono, R. N., Fikri, M. A. A., Asbari, M., Suroso, Nugroho, Y. A., \& Singgih, E. (2020). The Role of Employee Engagement in the Relationship between Authentic Leadership, Talent Management and Job Satisfaction. International Journal of Advanced Science and Technology, 29(5), 11809-11836. http://sersc.org/journals/index.php/IJAST/article/view/25377

[62] Sutardi, D., Novitasari, D., Asbari, M., Silitonga, N., Nugroho, Y. A., Hutagalung, D., Mustofa, Chidir, G., Basuki, S., \& Yu wono, T. (2020). Pengaruh Work-Family Conflict, Stres Kerja dan Social Support terhadap Kepuasan Kerja: Studi Kasus pada Guru Wanita di Tangerang. EduPsyCouns: Journal of Education, Psychology and Counseling, 2(1), 482-498. https://ummaspul.ejournal.id/Edupsycouns/article/view/513

[63] VU, H. M. (2020). Relationship between Work-Life Balance, Religiosity and Employee Engagement: A Proposed Moderated Mediation Model. The Journal of Asian Finance, Economics and Business, 7(10), 339-345. https://doi.org/10.13106/jafeb.2020.vol7.n10.339

[64] Wang, I.-A., Tsai, H.-Y., Lee, M.-H., \& Ko, R.-C. (2019). The effect of work-family conflict on emotional exhaustion and job performance among service workers: The cross-level moderating effects of organizational reward and caring. The International Journal of Human Resource Management, 1-22.

[65] Warokka, A., \& Febrilia, I. (2015). Work-family conflict and job performance: Lesson from a Southeast Asian emerging market. Journal of Southeast Asian Research, 2015(2015), 1-14.

[66] Wening, N., \& Choerudin, A. (2015). The influence of religiosity towards organizational commitment, job satisfaction and personal performance. Polish Journal of Management Studies, 11.

[67] Xia, W., Guo, X., Luo, J., Ye, H., Chen, Y., Chen, S., \& Xia, W. (2021). Religious Identity, Between-group Effects and Prosocial Behavior: Evidence from a Field Experiment in China. Journal of Behavioral and Experimental Economics, 101665. https://doi.org/https://doi.org/10.1016/j.socec.2021.101665

[68] Yuwono, T., Novitasari, D., Asbari, M., Sutardi, D., Mustofa, \& Asbari, M. (2020). Peran Organizational Commitment terhadap Hubungan Work- Family Conflict dan Kepuasan Kerja Karyawan Wanita di Kota Seribu Industri Tangerang. EduPsyCouns: Journal of Education, Psychology and Counseling, 2(1), 524-540. https://ummaspul.e-journal.id/Edupsycouns/article/view/526/303

[69] Yuwono, T., Novitasari, D., Hutagalung, D., Sasono, I., Silitonga, N., \& Asbari, M. (2020). Peran Organizational Justice terhadap Komitmen Organisasional: Analisis Mediasi Kepuasan Kerja Dosen Perguruan Tinggi Swasta. EduPsyCouns: Journal of Education, Psychology and Counseling, 2(1), 582-599. https://ummaspul.e-journal.id/Edupsycouns/article/view/550

[70] Zaman, M. N., Novitasari, D., Goestjahjanti, F. S., Fahlevi, M., Nadeak, M., Fahmi, K., Setiawan, T., \& Asbari, M. (2020). Effect of Readiness to Change and Effectiveness of Transformational Leadership on Workers ' Performance during Covid-19 Pandemic. Solid State Technology, 63(1s), 185-200. http://www.solidstatetechnology.us/index.php/JSST/article/view/708 